\title{
Lithic industries, territory and mobility in the western Linear Pottery Culture
}

\author{
Pierre Allard ${ }^{1}$, Solène Denis ${ }^{1,2}$ \\ 1. UMR 7055 Préhistoire et Technologie, CNRS. 21, Allée de l’Université, 92023. Nanterre Cedex, France. \\ Email: pierre.allard@cnrs.fr \\ 2. Department of Archaeology and Museology, Masaryk University. Bud. M/114, Joštova 220/13, 662 43. Brno, \\ Czech Republic. Email: solene.denis@phil.muni.cz
}

\begin{abstract}
:
Territory is a complex notion whose definition varies depending on the discipline in which it is applied. Research on the notion of territory has often focused on the Palaeolithic. Studies in this field are mainly based on comparisons between archaeological assemblages and ethnographic data, an approach originating from the work of L.R. Binford, who introduced the concept of mobility, leading to various models of spatial occupation. How have researchers approached the notion of territory with regard to the first mixed farming populations of the Linear Pottery Culture in the Seine Basin and neighbouring regions? Can lithic industries contribute to our understanding of how these first sedentary populations perceived their territory? In this paper, we show that these first Neolithic communities likely obtained their siliceous materials via direct procurement strategies across a territory that they knew well and regularly frequented. In our study area, centred around the RhineMeuse region and the Seine Basin, two distinct litho-spaces are comprised of: 1) small numbers of minor territories with local resources, and 2) vast territories requiring greater mobility among the groups that occupied them. Furthermore, the procurement strategies of the occupants of the regions with few siliceous resources seem to have been based on long-distance relationships and networks. In this case, a high degree of mobility and ensuing social relations would have contributed to the attractivity of villages.
\end{abstract}

Keywords: Early Neolithic; Linear Pottery Culture; Seine Basin; lithic industry; techno-economic analysis

\section{Introduction: the notion of territory in prehistory}

Territory is a complex concept whose definition varies depending on the discipline in which it is applied. Broadly, the notion of territory refers to a spatial entity circumscribed by its environmental, economic, political and ideological contexts, and which is organized in different manners depending on the observational scale. While it is not our intention to review the complete history of this notion, we begin this article by summarizing a few of its main principles.

Journal of Lithic Studies (2021) vol. 8, nr. 1, 24 p.

DOI: https://doi.org/10.2218/jls.4444

Published by the School of History, Classics and Archaeology, University of Edinburgh ISSN: 2055-0472. URL: http://journals.ed.ac.uk/lithicstudies/

Except where otherwise noted, this work is licensed under a CC BY 4.0 licence. 
Anthropological research has shown that the process of territorial organization must be analyzed based on the actions that humans perform on the material supports of their existence and their systems of representation: "A territory is thus objectively organized and culturally invented" (Bourgeot 1991: 704). In recent research, human geography has emphasized historical and cultural factors (Ripoll \& Veschambre 2005: 277-280), while political research has addressed the notions of limits, a central theme of territoriality (Kourtessi-Phillipakis \& Treuil 2011: 7-10). This notion of territory was applied early-on in studies of prehistoric cultures, especially by Anglo-American researchers whose theoretical models were largely based on ethnographic data. The most influential work in this field is that of L.R. Binford (1982), who introduced the concept of mobility and, based on its different forms, defined several models of spatial occupation. The two economic extremes that he defined are that of foragers, who exploit a limited environment around a very mobile campsite, and that of collectors, who, inversely, exploit a larger space around a more sedentary campsite.

In western Europe, research on the notion of territory has mostly focused on the Paleolithic. To define the mobility of human groups in a given space, researchers essentially rely on the circulation of human productions, and in particular, lithic raw materials (Bracco 1995: 290-292; Floss 1994: 312-320). A territory is defined as a frequented and exploited space (Jaubert \& Delagne 2007: 264-265) or the distribution zone of a specific type of object (Féblot-Augustin 1997: 227-231; Kozłowski 2005: 101-106). To refine this perspective, Delvigne defined the "litho-space" of an archaeological site as the geographic space delimited by the maximum extension represented by the origin of the raw materials found at the site (Delvigne 2016: 138). Integrating research in social and cultural geography, he proposed that a territory defined in this manner comprises named and well-identified spaces (whose hierarchy varies in function of the cultural value attributed to them), the itineraries linking them, and the empty spaces, which are rarely or only opportunistically frequented during periodic events (Delvigne 2016: 129-160). A nomadic space is thus structured as a set of networks that merges with the raw material circulation networks, which, for its populations, equals a territory (Delvigne, 2016: 150-151). More recently, the notion of "symbolic territories" was also addressed (Honoré et al., 2019) to enrich this approach to Paleolithic territories. For the Neolithic and other sedentary populations, researchers have turned to architectural groups (settlements, enclosure walls, graves, mines, etc.) and the degree of interdependence between them (Liétar 2017: 34-36). The definition of the environmental contexts in which mixed farming communities settled is superimposed on the spatial definition of territories, along with natural resource management. Therefore, "the coherence of a territory can be identified based on procurement networks and their limits" (Liétar 2017: 35). Raw material circulation is thus a secondary factor in the reconstruction of a territory, especially for societies with a strong hierarchization of sites and frequented-exploited spaces, such as the Middle Neolithic (Aubry et al. 2014: 66). This is not the case, however, for the beginning of the earliest Neolithic in continental Europe. The exceptional archaeological record of the Linear Pottery Culture, at the scale of the European Neolithic, is mainly composed of villages and necropolises. To define Early Neolithic territories, researchers have drawn from the internal structure of settlements, the interdependent relationships between sites, and the environmental data associated with site locations, as we will demonstrate in this article. However, we believe that the characteristics of raw material procurement strategies, identified via techno-economic approaches and the notion of litho-space, provide fundamental elements that can contribute to our understanding of how these first sedentary populations perceived their territories. 


\subsection{The Western Linear Pottery Culture}

The Linear Pottery Culture (LPC or Rubané) emerged to the north of the large Hungarian plains and the Carpathian Mountains during the transition from the Early to Middle Neolithic in the European chronology (Lichardus et al. 1985: 271-272). This complex is divided into two distinct entities: the Eastern Linear Pottery Culture and the Western Linear Pottery Culture. The latter represents the earliest phase of the "Danubian" cultures.

The LPC, one of the most widespread cultures in Europe during the Protohistoric period, is commonly divided into two major chronological periods (Figure 1). The first, named the älteste Bandkeramik ("the elder" Linear Pottery Culture), currently extends only as far as west as the Rhine River. During the second period, divided into four phases (II-V), the LPC extends from Normandy to Ukraine, thus across more than $2000 \mathrm{~km}$ from west to east (Figure 1 ). The earliest phase began in the first half of the $6^{\text {th }}$ millennium and the final phase (V) ended after the transition between the $6^{\text {th }}$ and $5^{\text {th }}$ millennia (5500-4900 BCE). The term "territory" has often been used to comprehend the distribution of sites during this period.

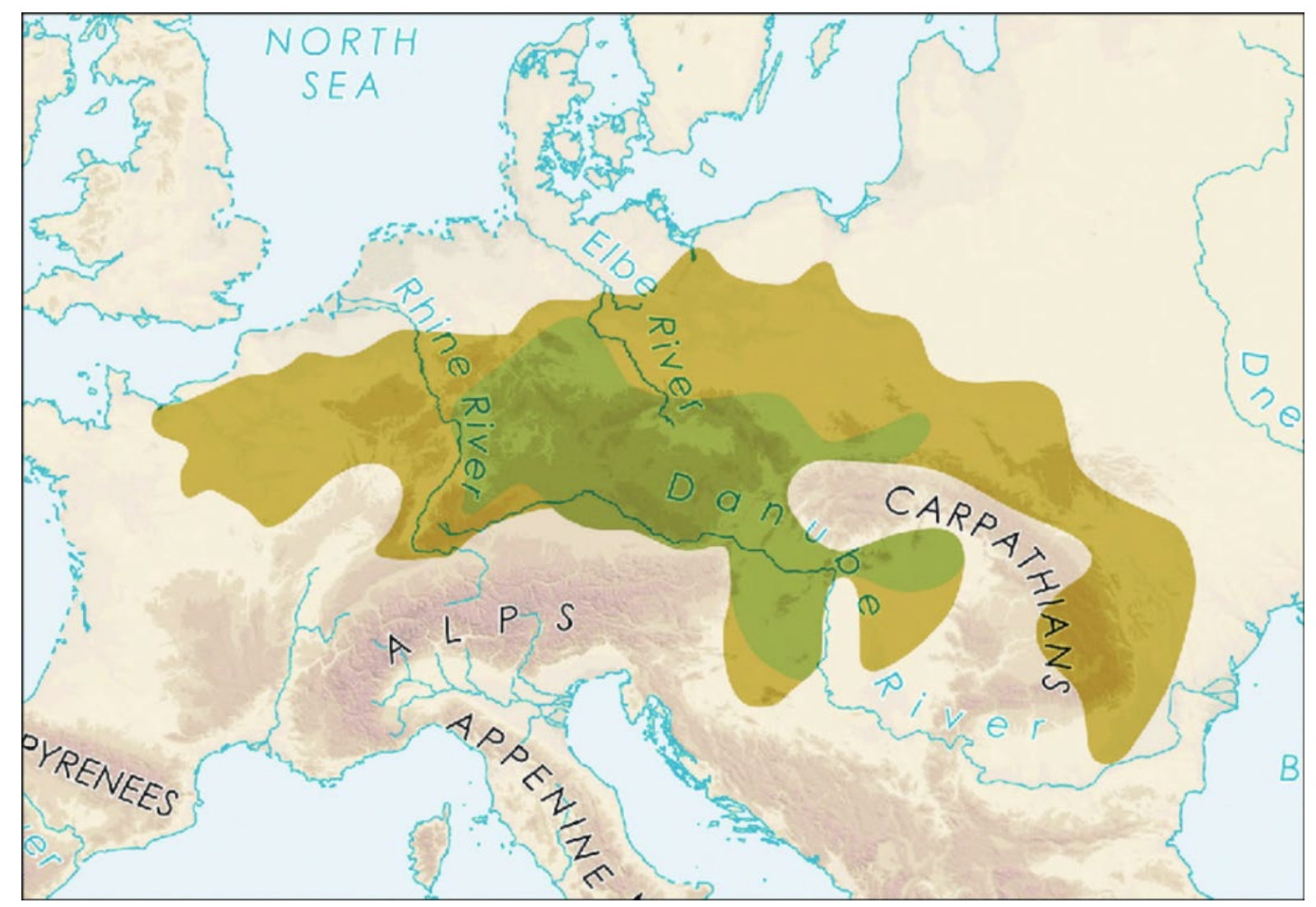

Figure 1. Map showing the distribution of the first farmers (Linear Pottery Culture) in Central Europe (S. Hansen, modified by E. Bánffy 2015). Green: Earliest Linear Pottery Culture; yellow: maximum extension of the Linear Pottery Culture.

\subsection{A territorial approach based on the structure of built spaces: different spatial entities}

There have been numerous studies of LPC settlements. The density of sites and houses in the villages in several zones of central and north-western Europe led to analyses of the structure and nature of the village space. Several imbricated spatial entities are thus frequently used to describe them, from the domestic unit to site networks at the micro-regional scale, the main aspects of which we will describe below (Figure 2). 

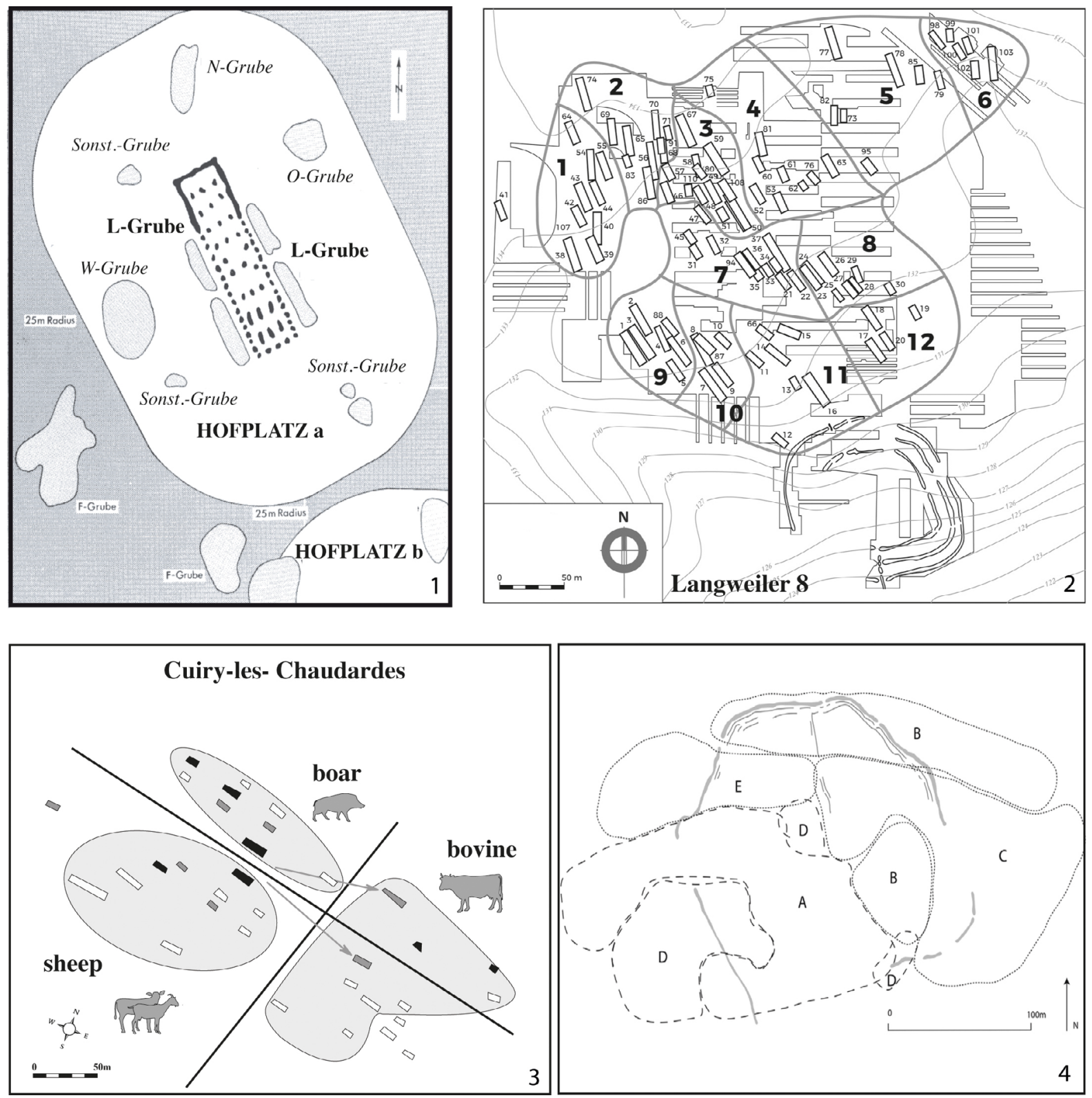

Figure 2. Household space with pits: the domestic era or Hofplatz (1) and Langweiler 8 settlement with 12 Hofplätze (2) (after Lüning 1988). Cuiry-les-Chaudardes (3) the village plan based on the fauna (Hachem 1997). Vaihingen an der Enz (4) plan showing the outline of the enclosure and palisades and the approximate extent of the clan groups and subgroupings (Bentley et al. 2013: 259).

\subsubsection{The domestic unit and village}

The ubiquitous architectural features of these houses are the main common denominator of the LPC. The dwelling unit has been described as a symbolic, identity-marking, memorial and ideological place (Bickle et al., 2016, Borić 2008: 124-126, Coudart 1998: 106-115). The house is composed of five parallel rows of posts with an internal space divided into two or three parts (Modderman 1970: 110-119, Soudský \& Pavlů 1972: 318), and is usually bordered by lateral trenches. Based on studies of the artefacts found in the structures, relative dates of the domestic units have been proposed, as well as a precise evolution of the settlement organization.

The phasing of site occupations shows that the houses were not randomly located in the village. Pioneering studies of the spatial structure of built spaces were based on the abundant 
data yielded by the Aldenhoven plateau in Rhineland, along the Merzbach Valley. This zone contains seven to eight villages, including three enceintes and approximately 160 LPC house plans (Lüning \& Stehli 1994: 110-123). The research conducted at the site of Langweiler 8 defined a zone with an average radius of $25 \mathrm{~m}$, containing the building, lateral trenches and a set of associated trenches. This group of buildings is called a farm (Figure 2.1). The spatial organization of the sites discovered at Langweiler shows that at least twelve generations of successive farms could have been constructed next to each other, with 20 to $60 \mathrm{~m}$ between them. All these generations delimit a space varying from $40-50 \mathrm{~m}$ to $80-130 \mathrm{~m}$. These spaces are designated as Hofplätze, which corresponds to land on which several generations of farms have succeeded each other (Lüning 1982; 1998). The villages, as we can observe them in their more or less complex final plan, thus correspond, for these authors, to a Hofplätze (Figure 2.2). This model strongly influenced studies of LPC village structures, and it is tempting to see in what has been identified as a Hofplätze (yard model), a form that could be identified as a parcel. This model has been criticized, in particular for the proposed internal organization of the village in rows of parallel houses situated along axes or around squares (Rück, 2012).

Various models have been proposed to explain the arrangement of the houses, some of which may have coexisted, such as in the Älteste Bandkeramik ("elder" Linear Pottery Culture) in Austria (Lenneis 2008: 168).

Other types of spatial settlement organization are also known. The exceptional site of Vráble in Slovakia, with 313 habitation unit plans and a unique structure, is divided into three distinct entities. Each entity is similar in size, approximately 15 ha. and separated by a stream and a depression (Furholt et al. 2020). An enceinte surrounds the south-western group of houses and, for this author, this tripartition, which could also suggest neighbourhoods, represents an intermediary level of organization between the house and the village.

This type of spatial partition can be further addressed by analyses of the artefacts discovered in the archaeological trenches. The faunal analysis at the site of Cuiry-lès-Chaudardes in the Aisne Valley (France) is quite informative, for example. The distribution of the osseous remains of the main species in the houses indicates a differential distribution among the neighbourhoods, independent of the evolution of the settlement's chronological phases. The author suggests that a symbolic representation may have been linked to the consumption of the three animal species, which would be related to an ideological structuring of the society and could reflect a clan-based village structure (Hachem 1997, Figure 2.3).

An analysis of the botanical remains at Vaihingen (Germany) also revealed variations interpreted as clan distinctions within the village (Figure 2.4). Each group would have practiced a slightly different cultivation strategy, identified in the weed spectrum. It is thus probable that the house groups used different fields (Bogaard et al., 2011).

\subsubsection{The village networks}

It is more difficult to study the organization of sites because this requires exhaustive excavations and studies of large village groups. Returning to the example of the Aldenhoven plateau in Rhineland (Germany), analyses have identified fifteen phases that show the evolution of the village establishments during the four occupation seasons on this plateau. The peopling of this zone began with a few houses at the site of Langweiler 8, followed by the emergence of peripheral settlements through time (Lüning 1982). Langweiler 8 is the only site that was continuously occupied throughout this period. The other sites were occupied intermittently and for shorter time periods, suggesting that Langweiler 8 could have played the role of "founder" for the other occupations in the region (Lüning 1998). The pre-eminence of this site was also shown by a study of its flint artefacts, indicating that it also played a key economic role. At Langweiler 8, there are more Rijckholt flint by-products procured in the 
regional environment than other types, and the site inhabitants could have redistributed some of this production to other sites in the form of preforms and finished products (Zimmermann 1995: 106-107). Sites of this nature are called "central places." Based on these results, the model proposed by Lüning suggests that in the Merzbach region, site clusters were structured around a central settlement. According to Lüning, these clusters comprised four to nine villages within a space of 3 to $9 \mathrm{~km}$ and were located 3 to $7 \mathrm{~km}$ from each other (Lüning 1998).

When this type of approach, involving the hierarchization of sites, was applied in the Aisne Valley, it also revealed a distinction between large villages with long-term occupations and small villages with short-term occupations. The long-term villages were spaced $18 \mathrm{~km}$ apart, and J. Dubouloz proposed that they represent "spatial markers of potential territories, fifteen to twenty kilometers long” (Dubouloz 2012: 25). Dubouloz also emphasized that the spatial extension of these territories is comparable to that of the Aldenhoven (after Lüning 1988) or Hesse (after Kneipp 1995).

Therefore, the inter-site models of the LPC often consist of a central village surrounded by other smaller ones (Figure 3). Stehli (1989) interprets this model as a pioneer establishment colonizing a region, with succeeding generations being established nearby. The site clusters are considered as territories (Dubouloz 2012: 25).

For the first mixed farming communities of central and north-western Europe, the notion of territory was essentially based on studies of the structure of built spaces, which were articulated around the domestic unit. This spatial entity seems to constitute the foundational social link structuring the activities of the first Neolithic communities. The territorial approach was thus mainly focused on the inter-organization of domestic spaces. How were the villages organized? What relationships are perceptible between the habitation units within a single village and between neighbouring villages? The autonomous domestic unit is thus considered as the central link connecting a network of social and economic relationships and interactions within a frequented and shared space, at least at the micro-zone scale, which is defined by the distribution of a central site and neighbouring hamlets (Dubouloz 2012: 22). However, we believe that the spatial entities described are associated with models that do not sufficiently consider the territory itself. This perspective must include the links between these first communities and their environment.

\section{A territorial approach structured according to the exploitation of an environment}

In her study of site organization in the Netherlands, C. C. Bakels (1982) worked at two observation scales to comprehend the distribution of sites on the landscape. The first observation scale addressed the relationships between sites and the geographic features of their landscape. In the early 80s, 32 LPC sites were recorded in the Netherlands, all concentrated in the southern part of the country. These settlements were built on a slight slope at least $750 \mathrm{~m}$ from a stream and on the side of a loess plateau. There is thus a strong correlation between these geographic features and the settlement locations. Topographic choices similar to those identified at these LPC settlements have also been observed in the Aisne Valley and the Hesbaye Liégeoise, for example (Dubouloz 2012: 23; Jadin 1999: 701). 


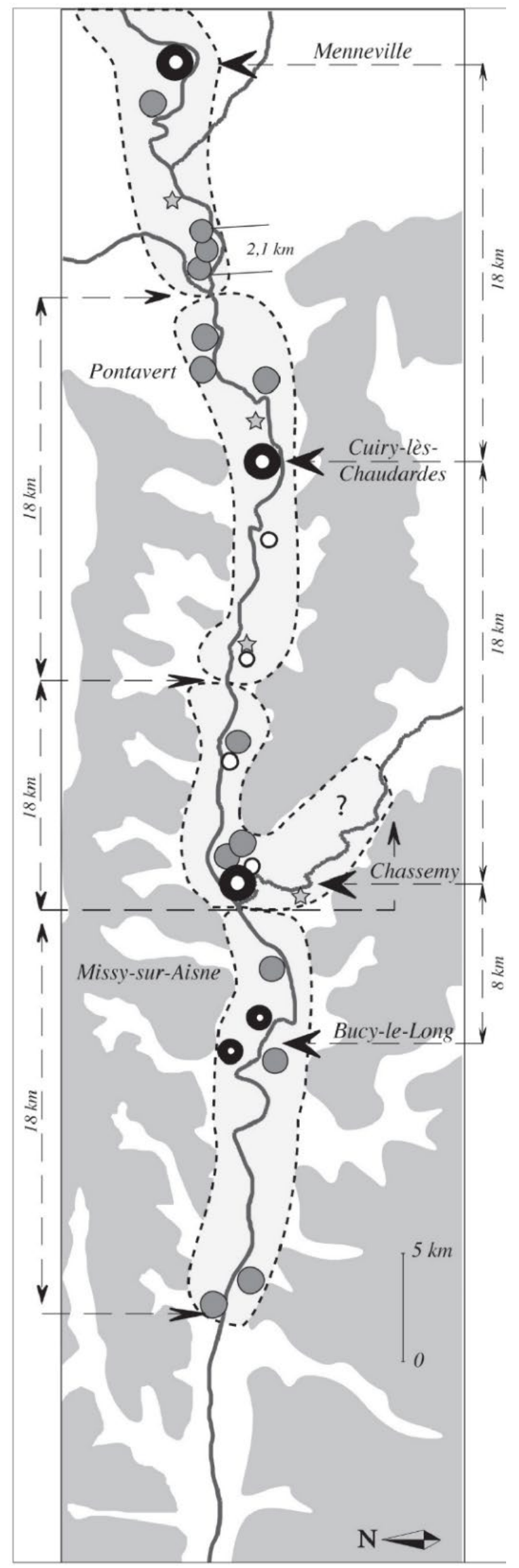

Figure 3. Diagram, proposed by Dubouloz (2012), of the potential territorial organization of Linear Pottery Culture sites in the Aisne valley. After Ilett \& Plateaux 1995, completed by the author. 
The second observation scale concerned the regional distribution of sites relative to each other. Apart from those located beyond the loess substrates, the great majority of sites are non-randomly grouped between the Meuse and Gueule rivers. Environmental factors may explain the choice of these locations: the region to the west of the Meuse and the north of the concentration do not have loess deposits. The southern part of the zone, on the other hand, lacks secondary streams and, consequently, easily accessible water sources. The chronology of these settlements shows that their number remained relatively stable, except in the late phase of the LPC when the number of sites significantly increased. The general distribution of the settlement locations is organized in small clusters.

To attempt to define the territory of a village based on a group of settlements from the recent phase, Bakels examined a detailed topography relative to the dry valleys. This analysis suggests the existence of what Bakels designated as the territories linked to each village, covering between 60 and 170 ha. (Figure 4). The needs of the communities were estimated based on our knowledge of their materials, and a list of the materials accessible in the territories of each village, and according to the settlement clusters, was compiled. Resources such as firewood, wood and plants for house construction, and silt for wall and vase construction were directly accessible in the supposed 60 to 170 ha. zones of each site. Stones for grinding tools, wood, a few local flint sources, and hunting zones were accessible at the scale of site clusters (the micro-zone, according to Dubouloz 2012: 22-25).

Rijckholt flint, on the other hand, was easily accessible in the region but in a zone beyond the limits of the site cluster. Other hard stones and hematite were clearly exogenous to the Netherlands Limbourg province considered here (Bakels 1982).

The study by Bakels thus offers a territorial perception at two scales of observation, integrating a historical dynamic of the peopling of a region. It is also possible to perceive a territory via the supposed relationships linked to the procurement of certain resources at the settlement cluster scale.

Following this same territorial perspective and integrating environmental data, Dubouloz identified "local spatial analysis schemas" (2012: 23), inspired by the concept of "site catchment analysis." These "schemas" aim to determine the proportion of agricultural lands relative to the other ecological zones (providing wild fauna and flora) within a $1 \mathrm{~km}$ zone around the sites - thus comparable to the territories modelled by Bakels. These "schemas" contribute to the modelling of territories based on the structure of built spaces. In the Aisne Valley, therefore, this distinction between large and small sites can be seen in these ecological zone "schemas". The larger sites have larger agricultural lands than the small sites, showing that this easy accessibility could have dictated the permanent installation of some LPC villages (Dubouloz 2012: 22).

The use of environmental data in the construction of LPC territorial settlement models shows that the local space corresponds to the subsistence economy of these populations and provides nearly all the necessary resources for a mixed farming lifestyle. However, stone procurement strategies concerning siliceous materials, in particular, seem to reveal a very different scenario. 


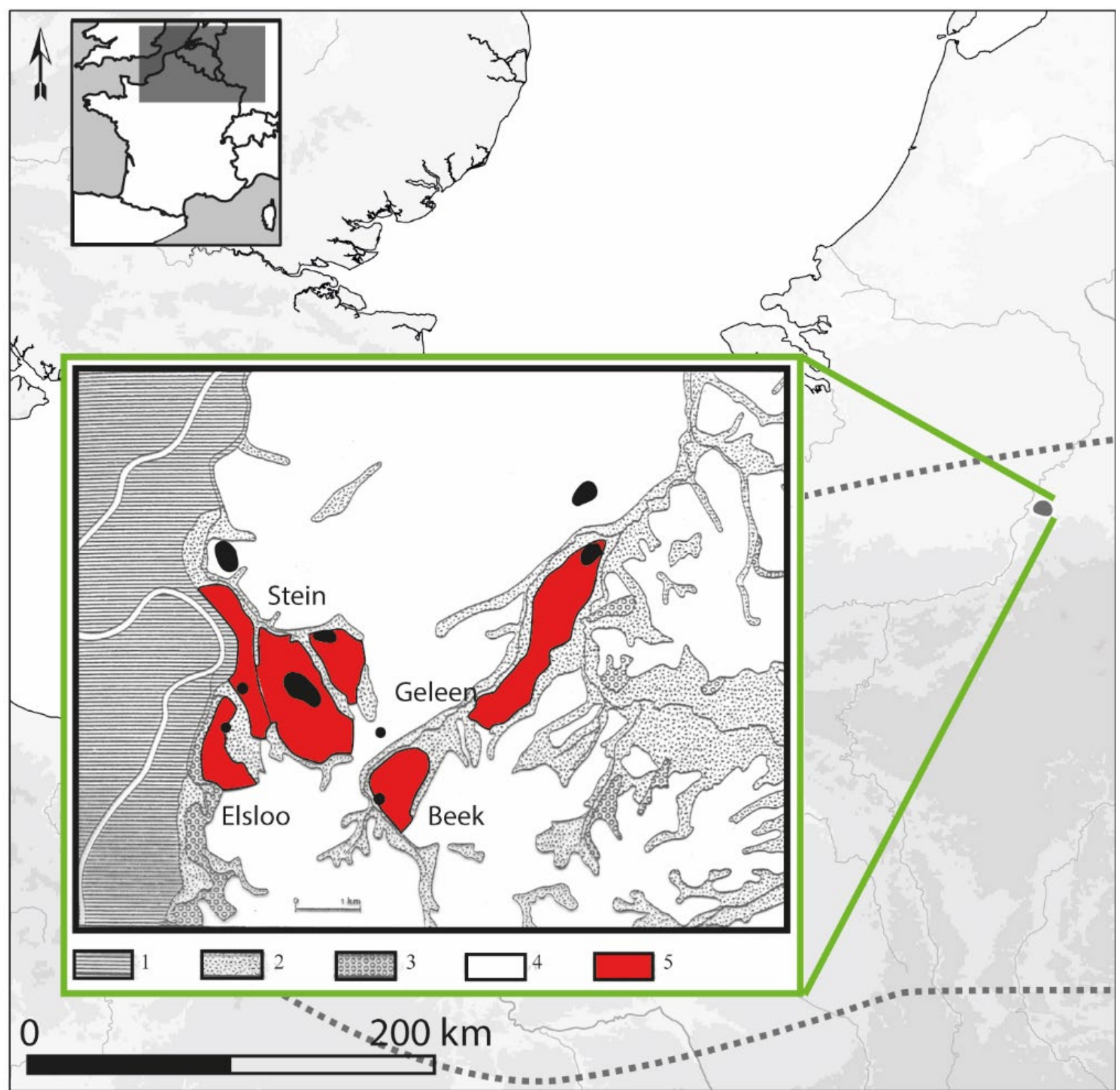

Figure 4. Possible site territories in the southern part of the Limburg province in the Netherlands (Stein, Elsloo, Beek and Geleen sites). 1: alluvial clay; 2: valleys and dry valleys; 3: sand and gravels exposed on slopes; 4: loess; 5: territories, modified after Bakels 1982.

\section{Decrypting the notion of territory via siliceous resource exploitation}

Several authors have demonstrated that LPC site locations were chosen independently of the proximity of siliceous resources (Allard 2005: 175; Cahen et al. 1986: 21). However, tools made from siliceous rocks are essential to mixed farming communities, and the procurement strategies associated with these materials are thus an important part of the economy of these populations. Siliceous material procurement strategies are thus highly relevant for analyses of the litho-space of these farming communities - defined as the geographic space defined by the maximum extension represented by the origin of the raw materials found at a site (after Delvigne 2016: 138).

\subsection{General features LPC lithic industries}

Flint tools are essential components of mixed farming activities and are systematically present in the habitation units of Danubian villages. Flint toolkits are rather homogeneous in 
the LPC, even if there are regional or chronological variations in the presence or frequency of a few specific tools. Burins, for example, are clearly more abundant in the LPC of the Seine Basin. What is remarkable is the stability of the laminar concept throughout the LPC distribution zone. Despite some variants, the flaking objective was always oriented toward obtaining small $(8-12 \mathrm{~cm})$ regular blades detached by indirect percussion. High-quality, often varied, materials were used to make these blades. Several varieties of siliceous rocks were used within the same site.

\subsection{Understanding Neolithic territories via the diversity of lithic procurement strategies}

In our research on the contribution of lithic industries to our understanding of Neolithic territories, we observed three broad configurations of the relationship between site locations and outcrops of siliceous rocks (Figures 5 and 6).

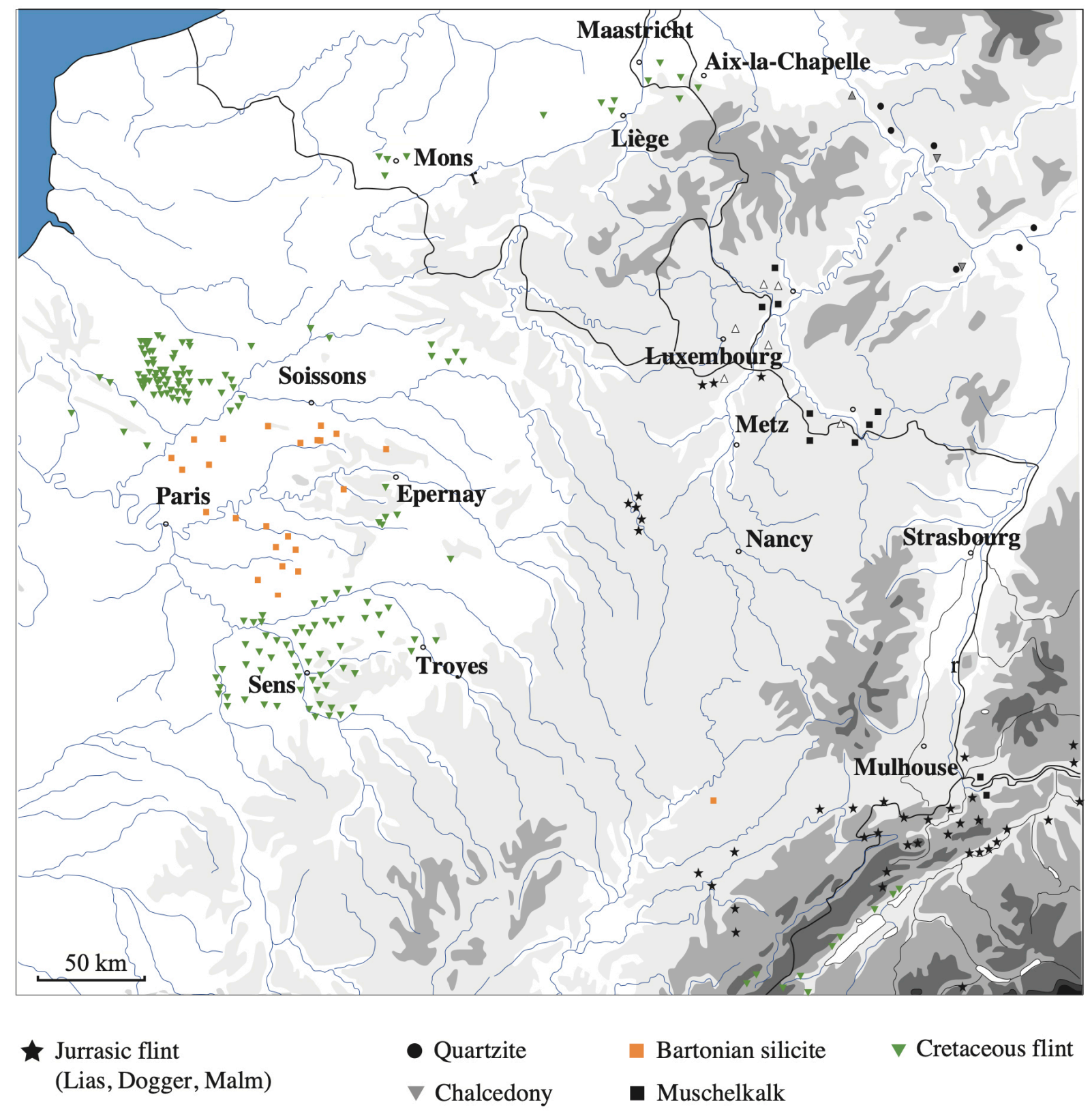

Figure 5. Map of the main flint types in northern France and Belgium (after Allard 2005, modified). 


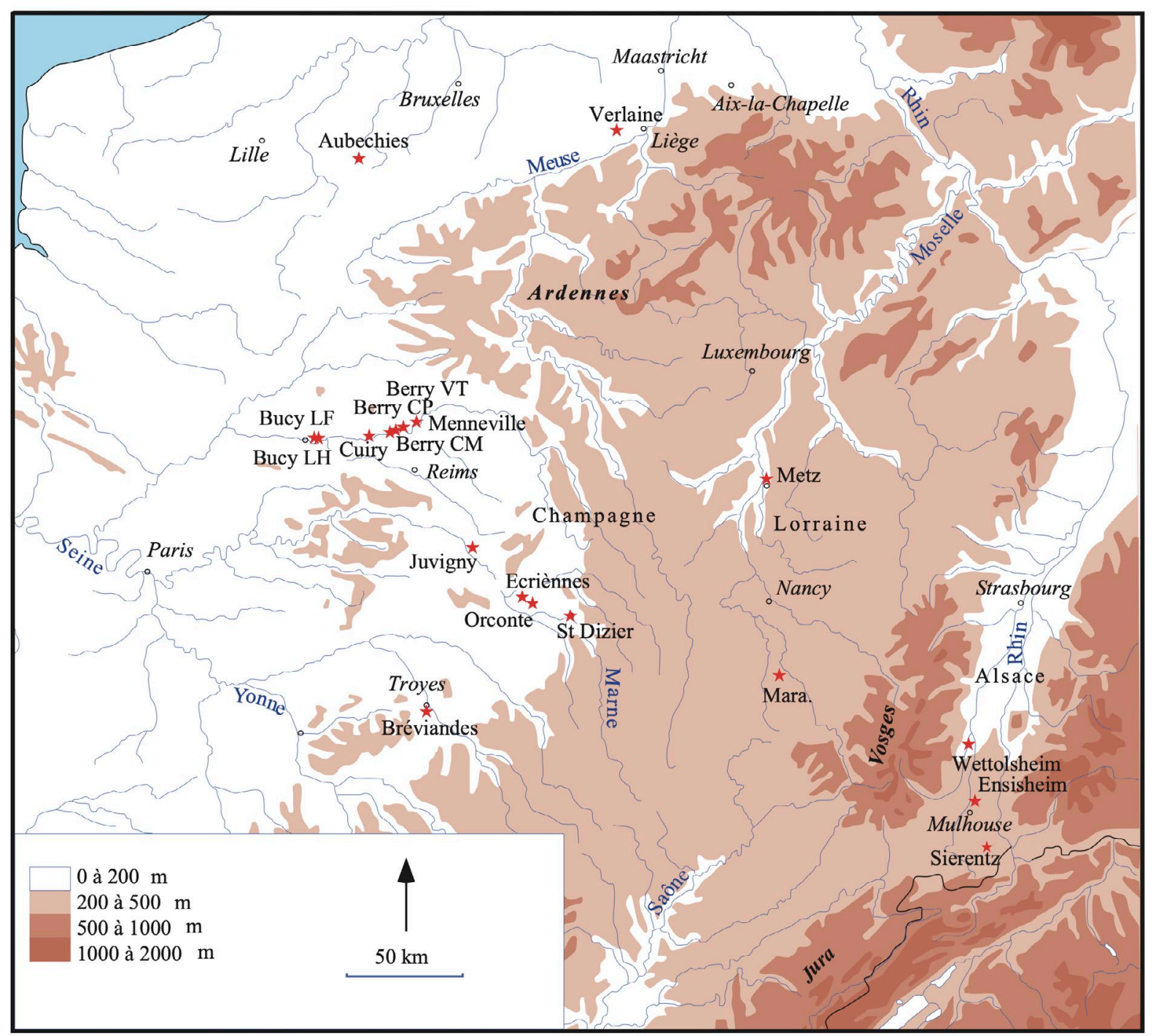

Figure 6. The main LPC sites mentioned in the text.

The first configuration consists of settlements located along alluvial valleys that traverse a geological landscape with abundant siliceous resources that are easily accessible in primary position or disturbed contexts. In the region studied here, this is the case for the Dutch province of Limburg, the Hesbaye region in Belgium, and the Bassée sites at the Seine and Yonne confluence in France. These occurrences are rare, and the populations procured siliceous materials almost exclusively in the immediate environment, and the assemblages are often very abundant. There is most often a predominant material, along with other periodically exploited flint types. We also find a few finished products in exogenous flints. At Verlaine in the Hesbaye liégeoise region (Belgium), the flint is even present in situ (Allard 2005: 128).

The second configuration comprises settlements or site clusters located in regions with high-quality flint resources but which are not included in the micro-zones. This configuration includes the LPC sites of the Aisne and Perthois in Champagne, the Caen plain in Normandy, Sungdau in Haute-Alsace (France), and the sites in the Dender Basin in Hainaut, Belgium. This is the most common situation. In this case, we often observe multidirectional procurement in the sense that the assemblages include several flint varieties from distinct sources. In the Aisne Valley or Hainaut, for example, the assemblages include at least four or five broad distinct types. In the Aisne area, regional flints were preferred over those from the local alluviums for laminar debitage, and there are strong contrasts between the habitation 
units or settlements. There was a clear qualitative preference for Senonian flints for laminar debitage. In this situation, the closest flint sources, in the Marne or Oise, are located 30-50 km from the settlements. The known sources of Tertiary Bartonian flint, frequently used for blade debitage, are located $20 \mathrm{~km}$ from the settlements. The primary Turonian formations are 15-20 $\mathrm{km}$ from the nearest sites, but these flints are also abundant in the alluviums. These flints were rarely exploited, except in the eastern sector of the LPC occupation in the Aisne Valley, including the sites located in the current commune of Berry-au-Bac. There is thus a true "frontier" at which the use rate of this flint becomes predominant, and then nearly exclusive, at the Berry-au-Bac la Croix Maigret and Menneville Derrière-le-Village sites (Allard 2005: 70; Plateaux 1993). The flint procurement territory in this second scenario is thus large and varied. It is also in this situation that we find local secondary materials used for expedient productions, such as blanks for bipolar flakes (pièces esquillées) on quartz pebbles in Alsace and Champagne or on small alluvial Turonian pieces in the Aisne.

Finally, the third scenario consists of settlement zones in which high-quality siliceous material sources are rare or absent. This is the case in the Moselle Valley in France and Luxembourg, and in Basse-Alsace. The lithic assemblages, in this case, are small and essentially composed of exogenous flint for the laminar productions. They originate from distant sources, sometimes several hundreds of kilometers away. Nevertheless, lithic sources of variable, sometimes high-quality flints, such as those of the Oxfordian in the CommercySaint Mihiel region, have been identified in Lorraine (Blouet 2005). These resources were rarely exploited, however, compared to the exogenous flints of the Rhin-Meuse (Rijckholt and Campanian from Hesbaye) and Marne regions (Senonian and Tertiary), introduced into these LPC settlements in the form of blades and blade tools (Blouet 2005). In Basse-Alsace, the situation is similar, but the assemblages appear to be even smaller, and the Neolithic people used diverse local lithic materials, especially for non-laminar productions (Mauvilly 2000).

The variable flint procurement modalities observed in the LPC village zones thus show that the litho-space exploited is not limited to villages and associated agricultural lands or even to the definition of territories associated with site clusters. It is thus necessary to identify the form in which the raw materials arrived in the villages, introducing the notion of direct or indirect procurement relative to the potential source, which is perceptible via a technoeconomic approach. Depending on the procurement and diffusion strategies, the procurement territory must be reconsidered because the circulation modalities of siliceous products -as described in the "down-the-line" or "central place of redistribution" (Renfrew 1984: 119) models- reduce the distances traveled to procure the products. The existence of true economic distribution networks for siliceous products throughout the LPC (Allard 2018; Lech 1987; 1990; Zimmermann 1995: 92-96) suggests that the recognition of a siliceous resource procurement territory must begin with an understanding of the settlement organizations. The case of Langweiler 8, located outside of our study area, is exemplary because this one site appears to manage the procurement and redistribution of siliceous products to the other sites (Zimmerman 1995: 106).

\subsection{Techno-economic approach: direct or indirect procurement?}

A techno-economic approach to lithic assemblages - meaning the articulation of the production stages represented (chaîne opératoire) and the flint types used - enables us to decode the procurement and redistribution strategies associated with the artefacts at sites. In a previous study, we retained 33 materials for fifteen studied sites (Allard 2005: 174-175). In our first attempts with all the 16 to 18 technological categories retained for inventories of each pit, we were not able to define the primary synthetic axes. For this reason, we simplified the categories and grouped them into eight broad representative classes: 
1) untreated blocks,

2) cortical flakes,

3) initial block preparation flakes detached by hard hammer percussion,

4) flakes detached by indirect percussion, including all the core maintenance flakes,

5) blades and blade tools,

6) flake tools,

7) tool fabrication waste-products, consisting mostly retouch flakes and tool spalls,

8) cores and hammers.

Our final category comprised the artefacts that we were not able to precisely attribute to a production sequence stage. The results of this techno-economic classification are represented in Figure 7. This simplified procedure revealed four main groups in the artefact composition.

- Group 1 corresponds to the assemblages in which debitage sequences are absent, and the artefacts are thus composed of finished products, tools, and used flakes (Figure 7, Group 1 ). When flakes are present, they generally comprise less than $15 \%$ of the artefacts. The distribution curve of this group logically shows a peak for blades and tools.

- Group 2 contains few pieces representing the first debitage phases. The proportion of cortical flakes is small, and the unretouched knapping products comprise less than one-third of the assemblage (Figure 7, Group 2). Therefore, the peak observed for blades and tools in Group 1 is also present here, but to a lesser degree. Blades are always more numerous than flakes associated with crested blade preparation and core maintenance.

- Group 3 always contains cortical flakes and a high proportion of unretouched debitage by-products, which are always at least two times more numerous than blades (Figure 7, Group 3).

- In Group 4 (Figure 7, Group 4), all stages of the production sequence are represented. There is a high proportion of cortical flakes (approx. 10\%), and preshaping and preparation flakes are also well represented. Unretouched knapping by-products dominate the assemblage (60\%), cores are perceptible (1\%), and blades and tools comprise only one-quarter of the assemblage.

Based on the production sequence stages at the sites (Figure 7), we can determine that groups 2, 3, and 4 were knapped in place. The quantitative variation between these diagrams represents the form in which the raw materials were introduced into the sites, ranging from untreated blocks (Group 4) to largely preformed cores (Group 2). Table 1 presents the classification by groups for all the sites and materials included in this study. It reveals broad trends in the production sequence representation at the sites, along with the distances to the raw material sources. The two sites of Group 4, Verlaine and Bréviandes, are that located nearest to the raw material sources $(0-15 \mathrm{~km})$. The distances to the sources for the Group 3 sites is between 15 and $70 \mathrm{~km}$, with a great majority of the sites located 15-30 km away. The Group 2 sites are also 15-70 km from the sources, but, in this case, most of the sites are 30-70 $\mathrm{km}$ from the sources. Finally, except for the Bartonian of Berry-au-Bac flint, the Group 1 sites are located more than $80 \mathrm{~km}$ from the flint sources.

These four techno-economic behaviour groups thus generally correspond to the distances to flint outcrops. The further the distance from the outcrops, the less evidence there is for onsite core preparation, with only finished or semi-finished pieces being present farthest distances. This analysis illustrates the utility of the notion of direct or indirect procurement according to the representation of production sequence stages and its ability to refine the notion of litho-space and, consequently, our perception of territory. 


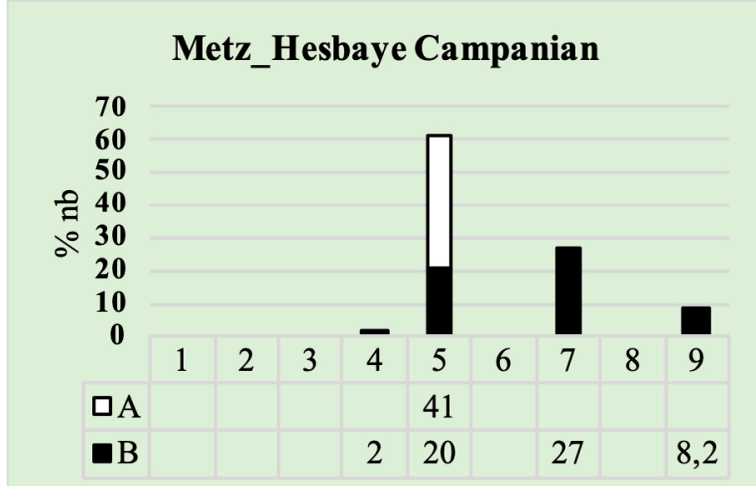

Group 1: techno-economic categories

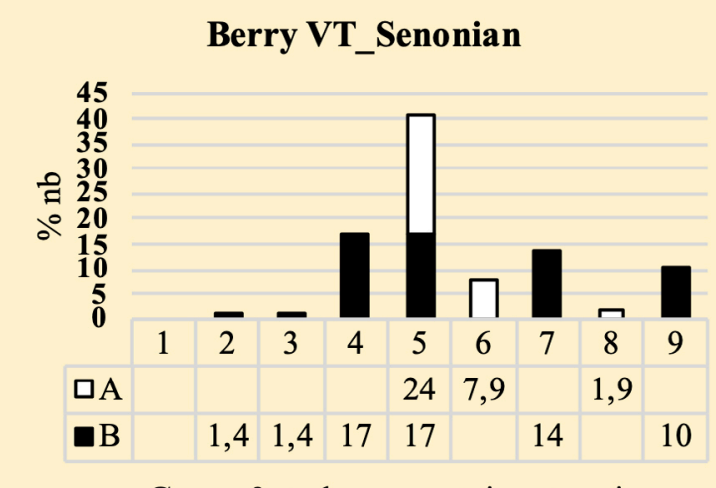

Group 2: techno-economic categories

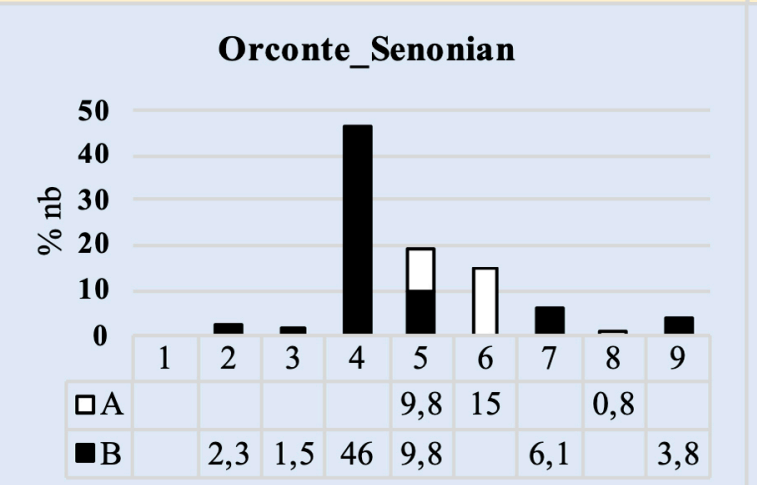

Group 3: techno-economic categories

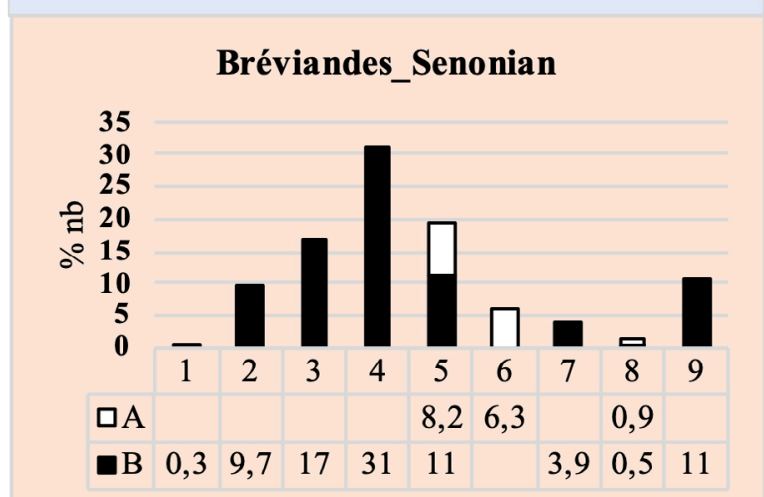

Group 4: techno-economic categories

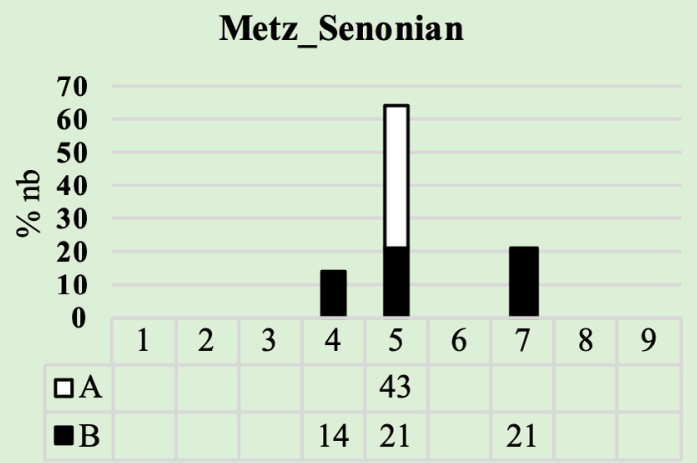

A : Tools, B : Debitage
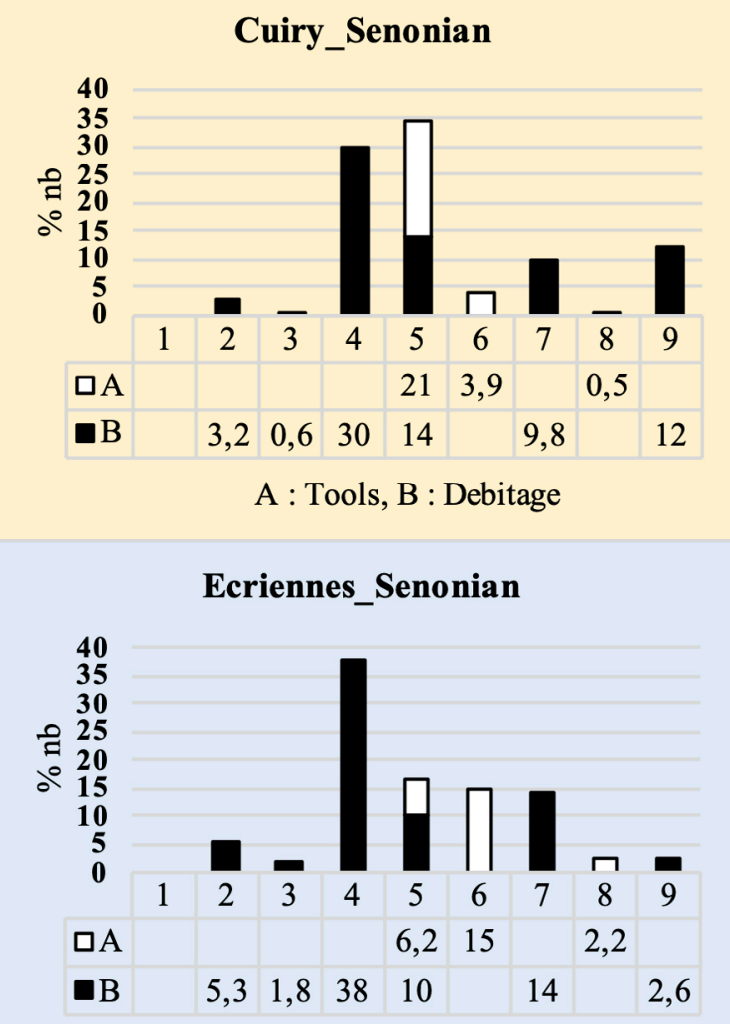

A : Tools, B : Debitage

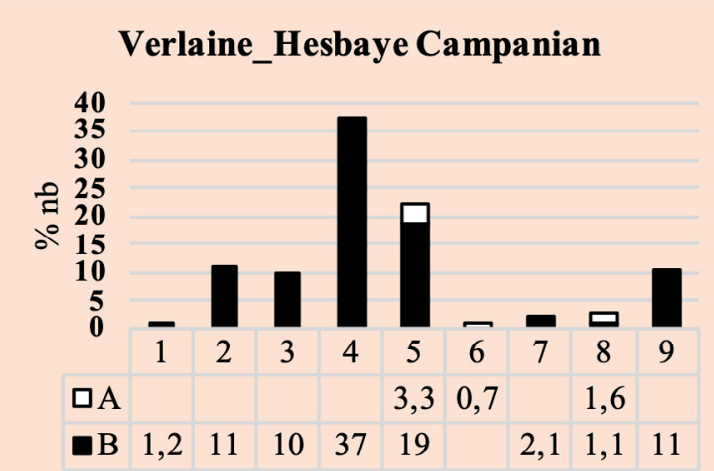

A : Tools, B : Debitage

Figure 7. The four techno-economic groups according the techno-economic categories: 1) untreated blocks, 2) cortical flakes, 3) preparation flakes detached by hard hammer percussion, 4) flakes detached by indirect percussion, 5) blades and blade tools, 6) flake tools, 7) tool fabrication waste-products, 8) cores and hammers, 9) not attributed 
Table 1. Classification by techno-economic groups of the studied sites according to the distance to the outcrops of the main raw materials identified at these sites.

\begin{tabular}{|c|c|c|c|}
\hline Site & Raw material & $\begin{array}{l}\text { Outcrop } \\
\text { distance }\end{array}$ & Groups \\
\hline $\mathrm{BCM}$ & Bartonian & $20-30$ & 1 \\
\hline Metz "Nord" & Senonian & $>80$ & 1 \\
\hline Metz "Nord" & Rijckholt & $>80$ & 1 \\
\hline Metz "Nord" & Campanian Hesb. & $>80$ & 1 \\
\hline Aubechies & Campanian Hesb. & $>80$ & 1 \\
\hline Wettholsheim & Senonian & $>80$ & 1 \\
\hline CCF & Turonian & $15-20$ & 2 \\
\hline Metz "Nord" & Regional & $15-30$ & 2 \\
\hline Wettholsheim & Jurassic Sie. & $15-30$ & 2 \\
\hline BVT & Bartonian & $20-30$ & 2 \\
\hline Juvigny & Bartonian & $30-40$ & 2 \\
\hline $\mathrm{CCF}$ & Senonian & $30-50$ & 2 \\
\hline BVT & Senonian & $30-50$ & 2 \\
\hline $\mathrm{BCM}$ & Senonian & $30-50$ & 2 \\
\hline Saint-Dizier & Senonian & $40-70$ & 2 \\
\hline BLF & Turonian & $15-20$ & 3 \\
\hline $\mathrm{BLH}$ & Turonian & $15-20$ & 3 \\
\hline BVT & Turonian & $15-20$ & 3 \\
\hline $\mathrm{BCM}$ & Turonian & $15-20$ & 3 \\
\hline Wettholsheim & Jurassic Wet. & $15-30$ & 3 \\
\hline Wettholsheim & Jurassic Ens. & $15-30$ & 3 \\
\hline Aubechies & Ghlin & $15-30$ & 3 \\
\hline Aubechies & Transluent & $15-30$ & 3 \\
\hline Verlaine & Maastrichtian & $15-30$ & 3 \\
\hline $\mathrm{CCF}$ & Bartonian & $20-30$ & 3 \\
\hline BLF & Bartonian & $20-30$ & 3 \\
\hline $\mathrm{BLH}$ & Bartonian & $20-30$ & 3 \\
\hline Juvigny & Senonian & $20-30$ & 3 \\
\hline BLF & Senonian & $30-50$ & 3 \\
\hline $\mathrm{BLH}$ & Senonian & $30-50$ & 3 \\
\hline Ecriennes & Senonian & $30-70$ & 3 \\
\hline Orconte & Senonian & $30-70$ & 3 \\
\hline Bréviandes & Senonian & $10-15$ & 4 \\
\hline Verlaine & Campanian Hesb. & $0-5$ & 4 \\
\hline
\end{tabular}

The two extremes on this production sequence continuum are easily distinguishable (groups 1-4, Figure 7): on one end, assemblages in which all the sequences are represented, and on the other end, assemblages in which only laminar products and tools are present. For Group 4, therefore, the raw material procurement can be qualified as indirect because there is little evidence of flint knapping in the habitation units. This scenario is characteristic of raw materials located at least $80 \mathrm{~km}$ from the sites. On the opposite end, the procurement is 
undeniably direct at the Group 1 settlements, which have access to many good-quality flint resources near the site $(0-15 \mathrm{~km})$.

The differences between groups 2 and 3 are seen in the artefacts associated with core preparation, which is shown by the importation to the site of pieces in various preshaping stages. The flint blocks are brought to the site as roughouts or ready to knap preforms, and the final reduction stages take place at the sites. This scenario thus consists of direct procurement, meaning it is conceivable in the case of procurement at the flint sources. However, even it is logical that the further the distance to the raw material sources, the greater number of pieces will be introduced in a ready-to-knap stage, the data shows that this relationship is far from systematic. While the interval of source distances for these groups is considerable - between 15 and $70 \mathrm{~km}$ - there is no observable distinction in the representation of production sequences for some of the flints at this interval.

By combining these three scenarios of settlement locations, material processing groups defined based on a techno-economic approach, and the known distances to raw material sources, it is thus possible to identify the coexistence of different procurement territories.

The most evident procurement territory concerns the sites located near raw material sources at which the procurement is direct. This local distance extends beyond the simple local framework usually recognized, however (Bostyn 1994: 71), such as at Bréviandes, where the first outcrops compatible with the assemblage are located $10 \mathrm{~km}$ from the site. In most cases, we observe that direct procurement can be deducted when the knapping byproducts attest to in situ flaking at the site. The distances indicate sources regularly located at 15 to $70 \mathrm{~km}$ from the villages, and cores are imported in more or less preshaped states. Finally, in the region considered here, raw materials from more than $80 \mathrm{~km}$ away are indirectly procured via highly structured circulation networks during the LPC.

\section{Discussion}

\subsection{Variable perceptions of LPC territories}

At a significant number of sites, the flint sources clearly attest to procurement ranges that are much greater than those of the local sources, including at the cluster level. Therefore, even if the identification of LPC territories via spatial entities and environmental data suggest that the local range provided most of the essential resources, an analysis of lithic procurement networks reveals that the communities were familiar with their extended environment as well. This is shown by the recurring presence of flint originating from sources located 15 to $70 \mathrm{~km}$ from the habitation sites and by pieces attesting to their production sequences. These elements, coupled with comparable blade production techniques among the different raw materials at a given site, proves that these communities had direct access to various raw material sources within a range of up to $50-70 \mathrm{~km}$. This limit has also been identified in other LPC contexts, such as in Germany (Strien 2017: 140).

The breaks - or frontiers - in the procurement zones, a phenomenon identified in the Aisne Valley (Plateaux 1993), Lorraine (Blouet 2005), and Hesbaye (Allard 2005: 189), raises many questions, such as the control of resources - was the knowledge shared? - or perhaps more simply, the organization of collection strategies. At the site scale, we can distinguish two behaviours. We sometimes observe a remarkable homogeneity in the frequency of different raw materials between the habitation units, or even the near exclusivity of a certain source. Inversely, significant variations are sometimes found among the contemporary houses at a single site or neighbouring sites. In the former case, we tend to see collective procurement at the village scale, while in the latter case, the variations could indicate procurement at the household scale. 


\section{Territory and mobility, in lieu of a conclusion}

Whatever the case, the locations of flint resource sites show that these populations frequented a territory much larger than that of a cluster. They knew their regional environment (defined for our study zone as $15-70 \mathrm{~km}$, according to our techno-economic analysis) and must have frequented it regularly. Site and object distributions have led some researchers to propose hypotheses related to the notion of mobility. This phenomenon is perfectly illustrated in the Lower Rhine Basin, from Belgium to Germany, where an increasing number of isolated typical LPC adzes have been discovered up to $150 \mathrm{~km}$ to the north of the settlements, nearly reaching the North Sea coast (Verhart 2012). In Bavaria, numerous isolated adzes have also been discovered in the Bavarian Forest, far from any settlements. Furthermore, in the low mountain ranges, hunting activities are suggested by occupied caves, and there is evidence of human incursions to procure the various raw materials that are found at the sites, such as granite, gneiss, graphite, and various sandstones of the Bavarian Forest (Hofmann et al. 2013: 216). There are generally few direct indices for the use of peripheral landscapes, far from the loess soils used for agriculture. Reconstructions of the catchment area of large sites, such as Stephansposching, suggest that these zones were used regularly and probably intensively (Pechtl 2009: 188-191). This indicates that the Bavarian Forest could have been widely used for forest pasturing and hunting trips lasting up to several days could have reached the Cham-Furth Basin.

Similarly, in Austria, three caves have yielded LPC pottery. It is thought that these sites probably represent seasonal camps for shepherds or hunters (Bickle et al., 2013: 167). This phenomenon is also known in France, in Alsace, via the discovery of LPC pottery in the Oberlarg caves, and in Jura at Bavans (Aimé \& Jeunesse 1986). Breeding and hunting must have contributed to an increased knowledge of the environment, which, beyond local activities, was not a place exterior to the community, but rather a frequented space that fostered relationships between different communities (Bickle 2016: 19-22). The notion of mobility is an increasingly prevalent element in our understanding of LPC communities (Hofmann 2020; Scharl \& Gehlen 2017: 9-18). Settlement structures are now thought of as being constructed, after searching for a favorable ecological niche, via migrations and continuous interactions (Bickle 2016: 15-17; Hofmann 2016; 2020). Settlement modalities and their propagation would thus be only one of the forms of movement rooted in the life of LPC communities, implying that mobility occurred at various spatial and temporal scales, from daily activities to migrations.

The notion of a flint procurement territory thus includes the concept of mobility, especially if we consider the circulation of exogenous siliceous products (flint tools and adzes).

The space frequented by these first Neolithic communities to obtain siliceous materials via direct procurement could be defined as a territory that was known and regularly frequented (Figure 8). Therefore, it does not correspond strictly to a Neolithic litho-space.

In our study zone, two distinct types of litho-spaces can be distinguished. One, not very frequent type is associated with small territories $(0-15 \mathrm{~km}$ in diameter) in which resources are locally available. The other type is associated with vast territories $(0-70 \mathrm{~km})$ that would have required high mobility on the part of the groups that occupied them. The litho-space of zones lacking high-quality flint and in which flint was clearly procured in a direct manner via circulations is vast. These zones were thus highly dependent on neighbouring territories and developed an exclusivity for one or the other of the surrounding territories, at least in the Moselle Valley, taken as an example here. This perspective suggests that we should reconsider the likely essential role of mobility. Taking again the example of siliceous materials, poor archaeological assemblages are correlated with the distance of the siliceous 
stone sources, but also with the importation of exogenous materials from diverse, sometimes very distant, sources. We put forward the principle here that this situation, for the inhabitants of these regions with few resources, would have required the development of social relations and networks larger than those of the settlements with easy access to local resources (Pavlü 2000: 260-264; Lech 1990). In this case, mobility would have been especially regular and involve extended social relations, which favored the attractivity of the villages. In terms of site size, we observe that the largest recorded sites are all located in zones with few lithic resources. In France, the recent discovery of the site of Bischoffsheim Afua du stade (Lefranc 2014), with 41 houses thus far excavated, is an example of a large site located in a region with almost no siliceous resources. Also, in this region, the site of Rosheim "Sainte Odile" appears to correspond to the notion of central sites due to its diverse artefact assemblage, indicating long-distance exchanges (Lefranc 2014). At the European scale, the recent discovery of Vráble in Slovakia, or the much earlier discovery of Bylany in Bohemia, is similar in this regard (Furholt et al. 2020). While not going as far as to propose a strict correlation with siliceous resources, following this study, we advance the possibility that the insufficient availability of an essential element of the resources needed by a community could encourage greater mobility and thus increase social relations, thereby making these regions more attractive via the exchange and circulation of goods and people.
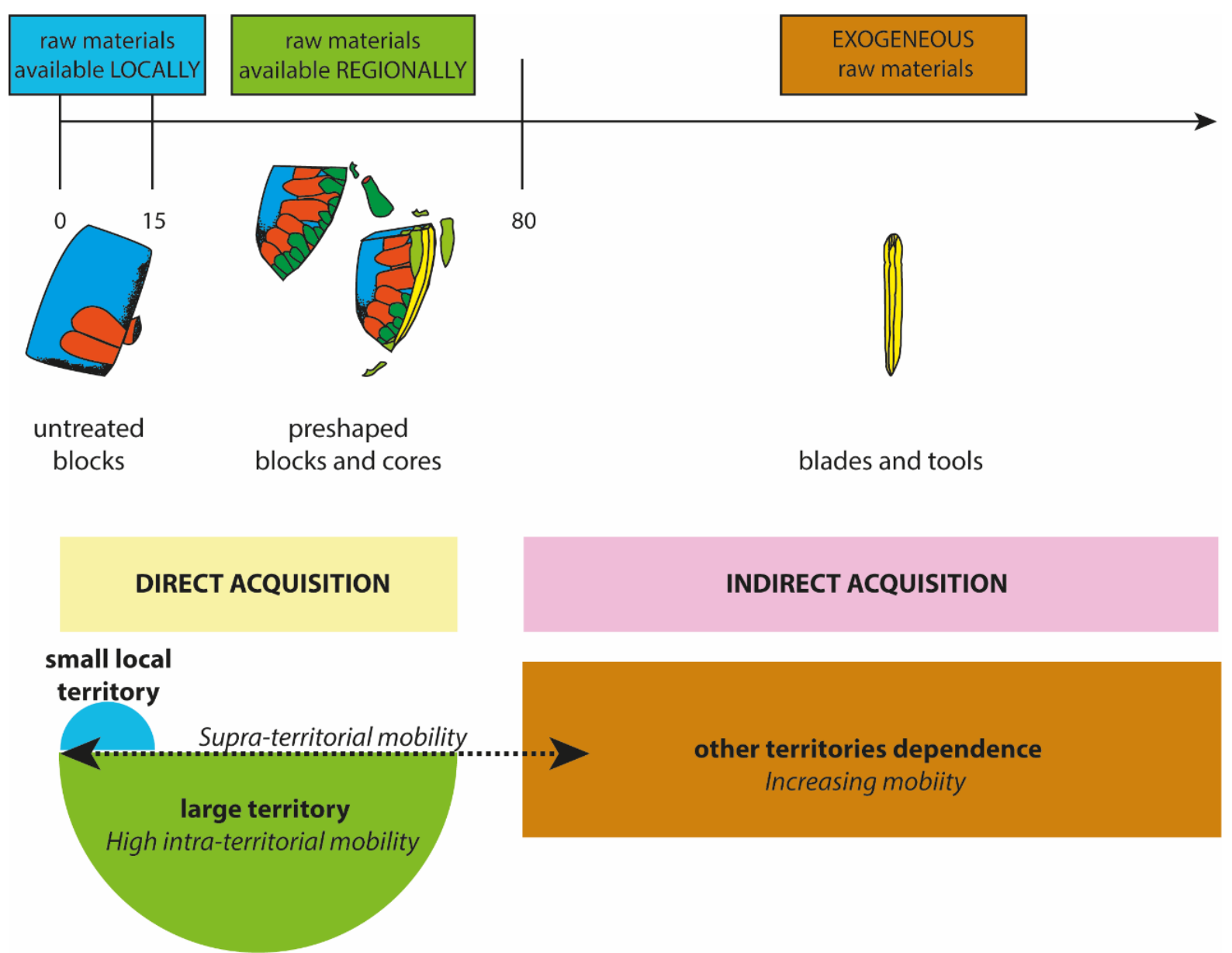

Figure 8. Schematic territories for flint procurement in the Paris Basin.

The association of resources obtained through both direct and indirect procurement can contribute to our understanding of the relationships between the different settlement zones and provide evidence of regular mobility patterns. 


\section{Acknowledgements}

Translation by Magen O’Farrell.

Corrections of the paper were supported by the Operational Programme Research, Development, and Education - Project "Postdoc2MUNI" (No.CZ.02.2.69/0.0/0.0/18_053/ 0016952).

\section{References}

Aimé, G. \& Jeunesse, C. 1986, Le niveau 5 des abris sous roches de Bavans (Doubs) et la transition Mésolithique récent/Néolithique dans la moyenne vallée du Doubs. In: Actes du $X^{\text {ème }}$ colloque interrégional sur le Néolithique, Caen, 1983 (Chancerel, A., Ed.), Revue Archéologique de l’Ouest, Supplément n 1, Rennes: p. 31-46. (in French) ("Level 5 of the Bavans rock shelters (Doubs) and the Recent/Neolithic Mesolithic transition in the Middle Doubs Valley”)

Allard, P. 2005, L'industrie lithique des populations rubanées du Nord-Est de la France et de la Belgique. Verlag Marie Leidorf GmbH, Rahden, 242 p. (in French) ("The lithic industry of Bandkeramik populations in North-East France and Belgium”) URL: https://www.vml.de/d/detail.php?ISBN=978-3-89646-358-6

Allard, P. 2018, Acquisition and Circulation of Flint Materials in the Linear Pottery Culture of the Seine Basin. In: Between History and Archaeology. Papers in honour of Jacek Lech (Werra, D.H. \& Woźny, M., Eds.), Archaeopress, Oxford: p. 165-172.

Aubry, B., Bostyn, F., Brunet, V., Collet, H., Giligny, F., Liétar, C. \& Manolakakis, L. 2014, Territoires et ressources lithiques dans le Nord de la France et en Belgique dans l'horizon Chasséen-Michelsberg. In: Zones de production et organisation des territoires au Néolithique. Espaces exploitées, occupés, parcourus, Actes du $30^{e}$ colloque interrégional sur le Néolithique (Louboutin, C. \& Verjux, C., Eds.), 51 ${ }^{\mathrm{e}}$ supplément à la Revue Archéologique du Centre de la France, Tours: p. 65-84. (in French) ("Territories and lithic resources in Northern France and Belgium in the Chasséen-Michelsberg horizon”) URL: https://halshs.archives-ouvertes.fr/hal-02551247

Bakels, C. 1982, The settlement system of the Dutch Linearbandkeramik. Analecta Praehistorica Leidensia, 15: 31-44.

URL: https://openaccess.leidenuniv.nl/handle/1887/28011

Bánffy, E. 2015, The beginnings of salt exploitation in the Carpathian Basin (6th-5th millennium BC). Documenta Praehistorica, 42: 197-209. doi:10.4312/dp.42.13

Bentley, R.A., Bickle, P., Francken, M., Gerling, C., Hamilton, J., Hedges, R., Stephan E.,Wahl, J. \& Whittle, A. 2013, Chapter 7: Baden-Württemberg. In: The first farmers in Central Europe: Diversity in LBK lifeways (Bickle, P. \& Whittle, A., Eds.), Oxbow Books, Oxford: p. 251-290.

Bickle, P. 2016, Varied mobility in the Neolithic: the Linerbandkeramik on the move. In: Moving on in Neolithic studies: Understanding mobile lives (Leary, J. \& Kador, T., Eds.), Oxbow Books, Oxford: p. 14-27.

URL: https://eprints.whiterose.ac.uk/98875/1/Chapter_2_Moving_On.pdf 
Bickle, P., Bentley, R.A., Blesl, C., Fibiger, L., Hamilton, J., Hedges, R., Lenneis, E., Neugebauer-Maresch, C., Stadler, P., Teschler-Nicola, M., Tiefenböck, B. \& Whittle, A. 2013, Chapter 5: Austria. In: The first farmers in Central Europe: Diversity in LBK lifeways (Bickle, P. \& Whittle, A., Eds.), Oxbow Books, Oxford: p. 159-204.

Bickle, P., Chan, B., Czerniak, L., Pyzel, J. \& Tsoraki, C. 2016, At Home in the Neolithic: Understanding Diversity in Neolithic Houses and Households. Open Archaeology, 2: 410-416. doi:10.1515/opar-2016-0029

Binford, L.R. 1982, The archaeology of place. Journal of Anthropological Archaeology, 1(1): 5-31. doi:10.1016/0278-4165(82)90006-X

Blouet, V. 2005, L’industrie lithique du site Rubané moyen de Malling « le Domaine des Primevères » (Moselle). In: Hommages à Claudine Pommepuy (Auxiette, G. \& Malrain, F., Eds.), Numéro spécial de la Revue Archéologique de Picardie 22, Amiens: p. 29-38. (in French) ("The lithic industry of the Middle LBK site of Malling « le Domaine des Primevères » (Moselle)”) doi:10.3406/pica.2005.2719

Bogaard, A., Krause, R. \& Strien, H.C. 2011, Towards a social geography of cultivation and plant use in an early farming community: Vaihingen an der Enz, south-west Germany. Antiquity, 85(328): 395-416. doi:10.1017/S0003598X00067831

Borić, D. 2008, First households and 'house societies' in European Prehistory. In: Prehistoric Europe: theory and practice (Jones, A., Ed.), Wiley-Blackwell, Oxford: p. 109-142.

Bostyn, F. 1994, Caractérisation des productions et de la diffusion des industries lithiques du groupe néolithique du Villeneuve-Saint-Germain. Ph.D. thesis at the Anthropology and Prehistory Department, Université Paris X Nanterre, Nanterre, 742 p. (in French) ("Characterization of the productions and diffusion of the lithic industry of the Villeneuve-Saint-Germain group”)

Bourgeot, A. 1991, Territoire. In: Dictionnaire de l'Ethnologie et de l'Anthropologie (Bonte, P. \& Izard, M., Eds.), Quadrige, Presses Universitaires de France, Paris: p. 704 (in French) (“Territory”)

Bracco, J.P. 1995, Déplacements des groupes humains et nature de l'occupation du sol en Velay (Massif Central, France) au Paléolithique supérieur: intérêt de l'étude des matières premières minérales. In: L’Homme méditerranéen (Chenorkian, R., Ed.), Université de Provence, Aix-en-Provence: p. 285-292. (in French) ("Movement of human groups and nature of land use in Velay (Massif Central, France) in the Upper Palaeolithic: Interest in the study of mineral raw materials”)

Cahen, D., Caspar, J.-P., \& Otte, M. 1986, Industries lithiques danubiennes de Belgique. Études et Recherches Archéologiques de l’Université de Liège 21. Liège, 88 p. (in French) ("Danubian lithic industries of Belgium”)

Coudart, A. 1998, Architecture et société néolithique : l'unité et la variance de la maison danubienne. Éditions de la Maison des Sciences de l'Homme, Paris, 242 p. (in French) ("Neolithic architecture and society: The unity and variance of the Danubian house")

Delvigne, V. 2016, Géoressources et expressions technoculturelles dans le Sud du Massif central au Paléolithique supérieur : des déterminismes et des choix. Ph.D. thesis, Université de Bordeaux, Talence, 3 vol., 1287 p. (in French) (“Georesources and technocultural expressions in the South of the Massif Central during the Upper Paleolithic: Determinisms and choices”) 
Dubouloz, G., with the collaboration of Chartier, M., Hachem, L. \& Ilett, M. 2012, Interdépendance et cohésion des différents niveaux de territorialité au Néolithique Rubané en Bassin parisien. In: Des Hommes aux Champs (Carpentier, V. \& Marcigny, C., Eds.), Presses Universitaires de Rennes, Rennes: p. 21-32. (in French) ("Interdependence and cohesion of the different levels of territoriality during the Linearbandkeramik in the Paris Basin”)

Féblot-Augustin, J. 1997, La circulation des matières premières au Paléolithique. Études et Recherches Archéologiques de l’Université de Liège, Liège, 2 vol., 522 p. (in French) ("The circulation of raw materials during the Paleolithic period")

Floss, H. 1994, Rohmaterialversorgung im Paläolithikum des Mittelrheingebietes. Romisch Germanisches Zentralmuseum, Bonn, 407 p. (in German) ("Raw material supply in the Palaeolithic of the Middle Rhine area”)

Furholt, M., Müller-Scheeßel, N., Wunderlich, M., Cheben, I. \& Müller, J. 2020, Communality and Discord in an Early Neolithic Settlement Agglomeration: The LBK Site of Vráble, Southwest Slovakia. Cambridge Archaeological Journal, 30(3): 469-489. doi:10.1017/S0959774320000049

Hachem, L. 1997, Structuration spatiale d'un village du Rubané récent, Cuiry-lès-Chaudardes (Aisne). Analyse d'une catégorie de rejets domestiques : la faune. In: Espaces physiques, espaces sociaux dans l'analyse interne des sites du Néolithique à l'Age du Fer, 119ème Congrès du CTHS, Amiens 1994 (Auxiette, G., Hachem, L. \& Robert, B., Eds.), éditions du Comité des travaux historiques et scientifiques, Paris: p. 234-245. (in French) ("Spatial structuring of a recent LPC village, Cuiry-lès-Chaudardes (Aisne). Analysis of a category of domestic discards: Fauna") URL: https://hal.archivesouvertes.fr/hal-02968856/

Hofmann, D. 2016, Keep on walking: The role of migration in Linearbandkeramik life. Documenta Praehistorica, 43: 235-251. doi:10.4312/dp.43.11

Hofmann, D. 2020, Not going anywhere? Migration as a social practice in the early Neolithic Linearbandkeramik. Quaternary International, 560-561: 228-239. doi:10.1016/j.quaint.2020.04.002

Hofmann, D., Pechtl, J., Bentley, R.A., Bickle, P., Fibiger, L., Grupe, G., Hamilton, J., Hedges, R., Schultz, M. \& Whittle, A. 2013, Chapter 6: Southern Bavaria. In: The first farmers in Central Europe: Diversity in LBK lifeways (Bickle, P. \& Whittle, A., Eds.), Oxbow Books, Oxford: p. 387-403.

Honoré, E., Lucas, C., Petrognani, S. \& Robert, E. (Eds.) 2019, Discussing the relevance and scope of 'Symbolic territories' for Prehistory. Quaternary International, 503B: 189190. doi:10.1016/j.quaint.2019.03.004

Ilett, M. \& Plateaux, M. (Eds.) 1995, Le site néolithique de Berry-au-Bac «Le Chemin de la pêcherie » (Aisne). Monographie du CRA 15. CNRS éditions, Paris, 220 p. (in French) ("The Neolithic site of Berry-au-Bac "Le Chemin de la pêcherie" (Aisne)”)

Jadin, I. 1999, Trois petits tours et puis s'en vont... La fin de la présence danubienne en Moyenne Belgique. Institut royal des Sciences naturelles de Belgique, Bruxelles, 724 p. (in French) ("Three little laps and then go away... The end of the Danubian presence in the middle Belgium”) 
Jaubert, J. \& Delagne, A. 2007, De l'espace parcouru à l'espace habité au Paléolithique moyen, Les Néandertaliens. In: Les Néandertaliens, Biologie et cultures (Vandermeersch, B. \& Maureille, B., Eds.), Éditions du Comité des travaux historiques et scientifiques, Paris: p. 263-281. (in French) ("From travelled space to inhabited space in the Middle Paleolithic, The Neanderthals”)

Kneipp, J. 1995, Frühbäuerliche Siedlungsverbände am Diemel, Esse und Unterer Fulda. Gedanken zur sozialen und wirtschaftlichen Struktur vor 7000 Jahren. Zeitschrift des Vereins für Hessische Geschichte und Landeskunde, 100: 1-19. (in German) ("Early farming settlements network on the Diemel, Esse and Unterer Fulda. Thoughts on the social and economic structure 7000 years ago")

URL: http://www.vhghessen.de/inhalt/zhg/ZHG_100/Kneipp_Siedlunbsverbaende.pdf

Kourtessi-Philippakis, G. \& Treuil, R., (Eds.) 2011, Archéologie du territoire, de l'Egée au Sahara. Publications de la Sorbonne, Paris, 323 p. (in French) (“Archaeology of the territory, from the Aegean to the Sahara”)

Kozłowski, J.K. 2005, La notion du territoire dans le Paléolithique. In: Comportements des hommes du Paléolithique moyen et supérieur en Europe : territoires et milieux. Actes du colloque du G.D.R. 1945 du CNRS, 2003, Paris (Vialou, D., Renault-Miskovsky, J. \& Patou-Mathis M.H., Eds.), Études et Recherches Archéologiques de l’Université de Liège, vol. 111, Liège: p. 101-106. (in French) ("The concept of territory during the Palaeolithic”)

Lech, J. 1987, Danubian raw material distribution patterns in eastern central Europe. In: The human uses of flint and chert (Sievering, G. de G. \& Newcomer, M.H., Eds.), Cambridge University Press, Cambridge: p. 241-248.

Lech, J. 1990, The organization of siliceous rock supplies to the danubian early farming communities (LBK), central european examples. In: Rubané et Cardial, Actes du Colloque de Liège, 1988 (Cahen, D. \& Otte, M., Eds.), Études et Recherches Archéologiques de l’Université de Liège 39, Liège: p. 51-59.

Lefranc, P. 2014, Les villages du Néolithique ancien en Alsace. Un état de la recherche. Archéopages, 40: 18-25. (in French) ("Villages of the Early Neolithic in Alsace. A state of research”) doi:10.4000/archeopages.588

Lenneis, E. 2008, Perspectives on the beginnings of the earliest LBK in east-central Europe. In: Living well together (Bailey, D.W., Whittle, A. \& Hofmann, D., Eds.), Oxbow books, Oxford: p. 164-178.

Lichardus, I. \& Lichardus-Itten, M. with the collaboration of Bailloud, G. \& Cauvin, J. 1985, La Protohistoire de l'Europe. Presses Universitaires de France, Éditions Nouvelle Clio, Paris, 640 p. (in French) ("The Protohistory of Europe")

Liétar, C. 2017, Territoires et ressources des sociétés néolithiques du Bassin parisien : le cas du Néolithique moyen (4700-3800 av. n.è.). Archaeopress Archaeology, Oxford, 178 p. (in French) ("Territories and resources of Neolithic societies in the Paris Basin: the case of the Middle Neolithic (4700-3800 BCE)”)

Lüning, J. 1982, Research into the Bandkeramik settlement of the Aldenhovener Platte in the Rhineland. Analecta Praehistorica Leidensia, 15: 1-30.

URL: https://scholarlypublications.universiteitleiden.nl/handle/1887/28075 
Lüning, J. 1988, Frühe Bauern in Mitteleuropa im 6. und 5. Jahrtausend v. Chr. Jahrbuch des Römisch-Germanischen Zentralmuseums, 35(1): 27-93. (in German) ("Early farmers in Central Europe in the 6th and 5th millennium BC”)

Lüning, J. 1998, L'organisation régionale des habitats rubanés : sites centraux et sites secondaires (groupements de sites). In: Organisation néolithique de l'espace en Europe du Nord-Ouest, Actes du XXIIIème colloque interrégional sur le Néolithique, oct. 1997, Bruxelles, 1997 (Cauwe, N. \& van Berg, P.-L., Eds.), Bulletin de la Société royale belge d'Anthropologie et de Préhistoire, 109, Bruxelles: p. 163-185. (in French) ("The regional organization of LBK settlements: central sites and secondary sites (groupings of sites)")

Lüning, J. \& Stehli P. (Eds.) 1994, Die Bandkeramik im Merzbachtal auf der Aldenhovener Platte. Beiträge zur neolithischen Besiedlung der Aldenhovener Platte 5, Rheinische Ausgrabungen 36. Rheinland-Verlag, Bonn and R. Habelt, Cologne, 556 p. (in German) ("The Linearbandkeramik in the Merzbach Valley on the Aldenhoven plateau")

Mauvilly, M. 2000, Le matériel lithique du site de Rosheim "Sainte-Odile" (Bas-Rhin). Première partie - objets en roches siliceuses et apparentées. Cahiers de l'Association pour la Promotion de la Recherche Archéologique en Alsace, 16: 67-81. (in French) ("The lithic material from the Rosheim site "Sainte-Odile" (Bas-Rhin). First part objects made of siliceous and related stones”)

Modderman, P.J.R. with contributions by Newell, R.R., Brinkman, E.J. \& Bakels, C.C. 1970, Linearbandkeramik aus Elsloo und Stein. Nederlandse Oudheden III. Rijksdienst voor het Oudheidkundig Bodemonderzoek, Amersfoort, 218 p. (in German) (“The Linear Pottery Culture at Elsloo and Stein”)

Pavlů, I. 2000, Bylany, life on a Neolithic site. Institute of Archaeology, Prague, 340 p. URL: http://bylany.com/pdf/BYLANY1_2000LIFE_EN.pdf

Pechtl, J. 2009, A monumental prestige patchwork. In: Creating communities: new advances in Central European Neolithic research (Hofmann, D. \& Bickle, P., Eds.), Oxbow Books, Oxford: p. 186-201.

Plateaux, M. 1993, Contribution à l'élaboration d'une problématique des matières premières pour le Néolithique récent dans le Bassin parisien. In: Le Néolithique du Nord-Est de la France et des régions limitrophes, Actes du XIIIème colloque sur le Néolithique, 1986, Metz, Documents d’Archéologie Française 41, Paris: p. 100-104. (in French) ("Contribution to the development of a research question on raw materials for the Recent Neolithic in the Paris Basin”)

Renfrew, C. 1984, Approaches to social archeology. Harvard University Press, Cambridge, $440 \mathrm{p}$.

Ripoll, F. \& Veschambre, V. 2005, Le territoire des géographes. Quelques points de repères sur ces usages contemporains. In: Les territoires du médiéviste (Cursente, B. \& Mousnier, M., Eds.), Presses Universitaires de Rennes, Rennes: p. 271-291. (in French) ("The territory of geographers. A few points of reference on these contemporary uses") 
Rück, O. 2012, Vom Hofplatz zur Häuserzeile. Das bandkeramische Dorf - Zeilenstrukturen und befundfreie Bereiche offenbaren ein neues Bild der Siedlungsstrukturen. In:

Siedlungsstruktur und Kulturwandel in der Bandkeramik. Beiträge zur internationalen Tagung 'Neue Fragen zur Bandkeramik oder alles beim Alten?' 23-24 September 2010, Leipzig (Cladders, M., Stäuble, H., Tischendorf, T. \& Wolfram, S., Eds.), Arbeits- und Forschungsberichte zur sächsischen Bodendenkmalpflege, Landesamt für Archäologie Freistaat Sachsen, Beiheft, Dresden: p. 20-42. (in German) ("From the farmstead to the house-row. The LPC village - house-row-structures and areas void of features reveal a new picture of settlement structures”)

Scharl, S. \& Gehlen, B. 2017, Mobility in Prehistoric Sedentary Societies. Kölner Studien zur Prähistorischen Archäologie 8. Verlag Marie Leidorf GmbH, Rahden, 300 p.

Soudský, B. \& Pavlů, I. 1972, The Linear Pottery Culture settlement pattern of Central Europe. In: Man, Settlement and Urbanism (Ucko, P., Tringham, R. \& Dimbleby, G., Eds.), Duckworth, London: p. 318-328.

Stehli, P. 1989, Merzbachtal-Umwelt und Geschichte einer bandkeramischen Siedlungskammer. Germania, 67(1): 51-76. (in German) ("Merzbach valley environment and history of a Linear Pottery settlement”) doi:10.11588/ger.1989.1

Strien, H.C. 2017, Group affiliation and mobility in the Linear Pottery Culture. In: Mobility in Prehistoric Sedentary Societies (Scharl, S. \& Gehlen B., Eds.), Kölner Studien zur Prähistorischen Archäologie Vol. 8, Verlag Marie Leidorf GmbH, Rahden: p. 135-144.

Verhart, L. 2012, Contact in stone: adzes, Keile and Spitzhauen in the Lower Rhine Basin. Neolithic stone tools and the transition from Mesolithic to Neolithic in Belgium and the Netherlands, 5300-4000 cal BC. Journal of Archaeology in the Low Countries, 4(1): 535. URL: http://jalc.nl/cgi/t/text/text-idxef89.html

Zimmermann, A. 1995, Austauschsysteme von Silexartefakten in der Bandkeramik Mitteleuropas. Universitätsforschungen zur prähistorischen Archäologie Vol. 26. Verlag Dr. Rudolf Habelt GmbH, Bonn, 162 p. (in German) ("Exchange systems of flint artefacts in the LPC of Central Europe”) 